\title{
How Does the Image of Yogyakarta Can Affect Tourist's Satisfaction and Their Post Behaviors?
}

\author{
Alveriansyah Haznam Mulya ${ }^{1}$, Daniel Tumpal Hamonangan Aruan ${ }^{2}$ \\ \{alveriansyah.h@ui.ac.id',dtumpal@ui.ac.id² \\ University of Indonesia, Jakarta, $10440^{1}$, University of Indonesia, Jakarta, $10440^{2}$
}

\begin{abstract}
Tourism has been one of the promising industry in Indonesia for several years. However, the study of tourism in Indonesia as an object of the research is still lacking. This study shows the most important dimension of destination image among domestic and international tourists in Yogyakarta. The data was collected between February - May 2020 through an online survey and was analyzed by applying partial least structural equation modeling (PLS-SEM). The analyses of data collected from 254 tourists depicted that all destination image's dimensions positively affect tourist's satisfaction and their future behaviors. The most influential dimension was affective image while cognitive image became the least effective. Managerial implications are discussed with limitations and future recommendations in the last section of this paper.
\end{abstract}

Keywords: tourism management, destination image, cognitive image, affective image, unique image, revisit intention, tourists loyalty.

\section{Introduction}

For several years, the travel and tourism industry became a leading sector in supporting a country's economic growth. This industry generates large money and has an impact on increasing the growth of other industrial sectors, such as hospitality, restaurant, rent house, etc. Travel and tourism have contributed $10.4 \%$ of global GDP and created 10\% (319 million) new jobs globally in 2018. Therefore, the stakeholders should consider what factors influencing travelers to choose a certain destination for travel. Based on previous studies about tourism, the destination image is one factor that will influence tourist's behaviors. It will have an impact on destination choice, revisit intention, or even share intention to other people [1], [2], [3], [4].

Some studies have stated that destination image is formed from tourist's interpretation to the physical characteristic of a destination (cognitive image) and how they feel or react (affective image) to the destination that they have visited earlier [5], [1], [3], [6]. Then, some studies add a conative to their model for seeing how will the tourists perceived a destination image of a particular destination [4]. This dimension tells about the activities that tourists will do after they cognitively and affectively perceived the image of destination [4]. However, Qu et al. [7] think that there is one additional dimension that can distinguish a destination with the others as an option for travel. This dimension is called a unique image, which can be a measure for stakeholders to assess the tourism industry in a certain destination. Furthermore, many researchers have used this dimension in forming destination image of one destination and found that unique image has a positive association with the overall image of one destination [7], [8], [9], [10], [11], [12]. 
Table 1. International Tourist Arrival Number

\begin{tabular}{crcc}
\hline & \multicolumn{3}{c}{ Number of International Tourist } \\
Arrival Gate & $\mathbf{2 0 1 7}$ & $\mathbf{2 0 1 8}$ & $\mathbf{2 0 1 9}$ (as of November) \\
& & & \\
Ngurah Rai & 5.682 .248 & 6.025 .760 & 5.710 .467 \\
Soekarno-Hatta & 2.749 .321 & 2.814 .586 & 2.244 .504 \\
Juanda & 247.166 & 320.529 & 227.659 \\
Kualanamu & 246.551 & 229.586 & 224.155 \\
Husein & 166.857 & 155.566 & 143.169 \\
Sastranegara & 145.673 & 138.822 & 103.837 \\
Adi Sucipto & & & \\
\hline
\end{tabular}

Though we have found so many studies about destination image globally, the study for big cities in Indonesia is still limited. For example, Yogyakarta has so many potential factors to be an attractive city for tourism. However, the fact stated that tourist arrival numbers to Yogyakarta still below the number of Surabaya, Medan, and even Bandung. Therefore, the purpose of this study is to see the effect of destination image of Yogyakarta towards satisfaction and tourist's future behaviors which in this case are revisit intention and share intention through social media. Through this study, we will know what factors which have more impact towards tourist's future behaviors in Yogyakarta. Thus, many implications can be used to enhance the industry in Yogyakarta.

\section{Literature Review}

\subsection{Destination Image}

Destination image refers to people's judgment towards a destination directly or nondirectly like magazines, brochures, or tourism websites. Based on Boulding [13], an image can influence human behavior than objective reality. Thus, destination image also can be defined as a total aggregate of beliefs, ideas, impressions, and expectations a tourist has perceived for a destination he/she will visits [14], [15]. Destination image plays an important role in every tourist's journey when having a trip to a certain destination. It can influence tourists to choose a destination, in the process of having satisfaction, and can affect their intention to revisit or sharing the experience with other people [4]. Many previous studies agree that the image itself is mainly formed by two major factors; stimulus and personal factors. The first factor is coming from the external such destination's physical attributes, while the latter factor is coming from the traveler's characteristic who will perceive the destination [1]. Therefore, prior studies argue that destination image composed of two dimensions; cognitive image and affective image. Based on Baloglu and McCleary [1], the combination of two dimensions influences the overall image, the evaluation of positive or negative towards the destination.

The cognitive image is referring to the physical appearance of the destination. It can be defined as an association that has been perceived by tourists after they saw the characteristics 
of a certain destination through some intermediary media [1]. Cognitive images can be landscapes, weather, culture, infrastructure, accommodation, or cleanlines. The second dimension of the destination image is the affective image, which can be defined as a perceived impression by the tourists towards a destination that they will visit [1]. This dimension refers to the evaluation stage regarding the associated feelings that an individual holds towards the destination [4], [1], [5]. It usually can be seen by tourist's happiness, perceived relaxation, local people friendliness, or sad during the travel. Therefore, we are hypothesizing that;

H1: Cognitive image has a positive impact on the overall image of Yogyakarta in tourist's perception

H2: Affective image has a positive impact on the overall image of Yogyakarta in tourist's perception

\subsection{Unique Image as New Dimension}

Many studies agree that destination image consists of four dimensions, which are cognitive image, affective image, and conative image that will influence the overall image perception in the traveler's mind [5], [16]. However, every entity should have their uniqueness to increase their opportunity to be chosen by travelers. Therefore, Qu et al. [7] have proposed a unique dimension image into a destination image that can differentiate a certain destination with other destinations. The unique image can also create an identity for a particular destination and create a different marketing strategy to have competitiveness against other destinations [9]. Based on Keller [17], brand uniqueness can be a factor to create a positive brand image. Therefore, this uniqueness can be very crucial to create the overall image of a particular destination in the traveler's mind [7], [8]. So, our third hypothesis is,

H3: Unique image has a positive impact on the visitor's overall image of Yogyakarta in tourist's perception

\subsection{Tourist's Satisfaction and Future Behaviors}

Satisfaction is considerably one method to measure how big the quality of a consumer's experience [18]. Based on Oliver [19], satisfaction is the result of the customer's evaluation of the differences between expectation and experience. Solomon [20] stated that satisfaction/dissatisfaction is a very important aspect of predicting a customer's future behaviors. Thus, in the tourism context, the images that have been perceived by tourists after they had a trip to a certain destination can lead to their level of satisfaction on what they experienced there. So, our fourth hypothesis,

\section{H4: Overall image has a positive impact on the visitor's satisfaction}

Many studies agree that destination image is one of the antecedents of tourist satisfaction and will lead to tourist's future behaviors [21], [22], [23], [24], [25]. Moreover, Wang and Hsu [22] stated that the destination image will affect the quality of satisfaction of the tourist. A more positive image perceived by the tourist will lead to higher satisfaction. One behavior that will be affected by satisfaction in the future is revisit intention [21]. Another one is referring the destination to other people through word-of-mouth [18]. These two things are very important to consider because, through these two factors, the level of loyalty from tourists can be measured to consider future marketing strategies. Revisit intention will be obtained when tourists have a positive image of the previous trip. Tourists who have very high revisit intention towards a particular destination tend to spread positive word-of-mouth to others and 
are more loyal [21]. Another action of loyalty by the customer is to share or recommend what they experience with other people, sometimes we called it Word of Mouth (WOM). WOM is said to be very effective because it is a personal opinion from those who have experienced certain brands, products, or services and the relationship between the two individuals is often very close. Therefore, positive WOM is the best factor to reduce the risk felt by tourists before traveling to a destination that has never been visited [7]. So, next hypotheses are;

\section{H5: Overall image has a positive impact on the visitor's share intention through social} media

\section{H6: Overall image has a positive impact on the visitor's revisit intention}

In the relationship between satisfaction and post-purchase behavior, it can be believed that satisfaction will have an impact on customer loyalty represented through repurchases and recommendations through positive WOM [25]. In the context of tourism, Loi et al. [21] said that the quality of local transportation services affects the intention of tourists to re-visit the destination. He also said that satisfaction is the strongest predictor of revisit intention for the destination and other destinations in the same country. Yoon and Uysal [23] study said that tourist satisfaction is the strongest indicator of revisit intention and intention to recommend to others. In their study, Loi et al. [21] found the results that the quality of transportation services (tourist shuttle) has a positive correlation as one of the constructs of the destination image that affects the revisit intention of the tourists. So, our last two hypotheses are;

H7: Tourist's satisfaction will mediate the relationship between the overall image and share intention through social media

H8: Tourist's satisfaction will mediate the relationship between the overall image and revisit intention

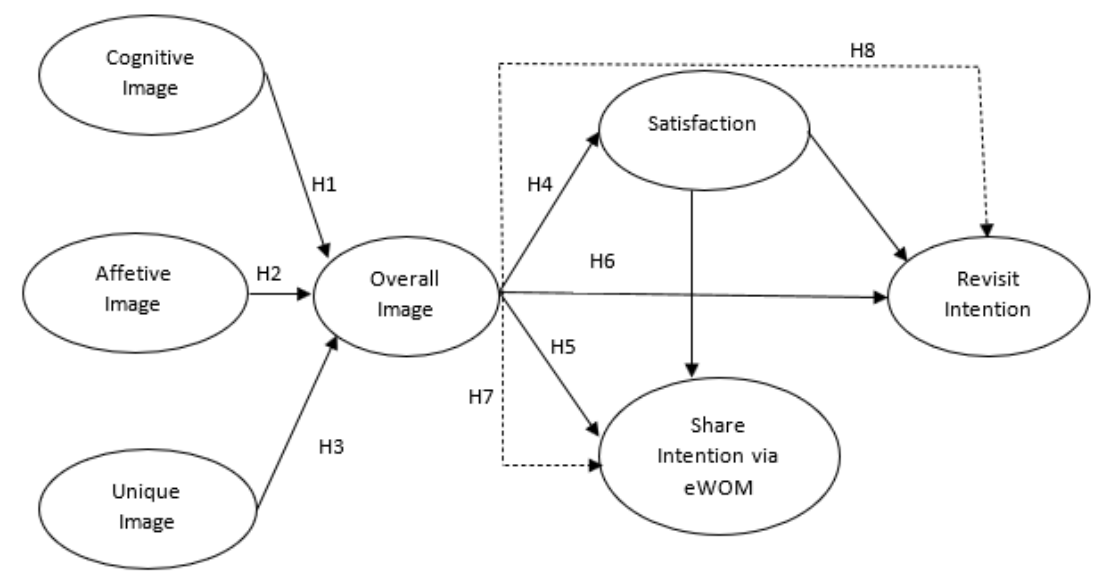

Fig.1. Research Model

So, Fig.1. shows how the correlation between variables formed in the current research. The current research model referes to Qu et al. [7] study by adding satisfaction variable to see its impact on destination image and tourist behaviors. 


\section{Method}

We collected 254 respondents in this study where the most population came from millennials $(204$ respondents $=80.31 \%$ ). 55.91\% of respondents came to Yogyakarta in the last 6-12 months. Most of the respondents came to Yogyakarta for holiday purposes (193 respondents $=75.98 \%$ ). Concerning the length of stay, $30.31 \%$ of respondents spend three days in Yogyakarta.

The survey consists of 7 parts which contain indicators of constructs for this study. In the beginning, the questions are about the respondent's background information, screening question, and some questions regarding the Yogyakarta trip experience. After that, we are going to the main topic of the research where we are asking some questions related to the cognitive image, affective image, unique image, and overall image in every section. There are 27 questions in the cognitive image section where the questions are applied based on Qu et al. [7] and adapted to the situation of the research object. We use a 5-point Likert scale $(1=$ strongly disagree; $5=$ strongly agree) to measure the indicators. For the affective image, we applied the measurement from Russel et al. [26]. We use a 7-points semantic-differential scale to measure Arousing-Sleepy, Pleasant-Unpleasant, Exciting-Gloomy, and RelaxingDistressing. The positive pole of the measurement located at the highest number $(1=$ Sleepy, 7 = Arousing; $1=$ Unpleasant, $7=$ Pleasant; $1=$ Gloomy, $7=$ Exciting; and $1=$ Distressing, $7=$ Relaxing). For the unique image dimension, we are also using Qu et al. [7] measurement and using a 5-points Likert scale. For the overall image section, we have only one question, which is "In general, how do you rate your perception of Yogyakarta destination?". We applied the question refer to Stern \& Krakover [27], Baloglu \& McCleary [1], and Qu et al. [7] studies. We use 7-points semantic-differential scale ( 1 = very negative; $7=$ very positive $)$.

For the next sections, we measure the tourist's satisfaction level, revisit intention, and share intention through social media after they visiting Yogyakarta. We use four indicators for satisfaction that we applied from Yoon and Uysal [23] study. The measurement uses a 5-point semantic-differential. In the revisit intention section, we measure the variable with two indicators from Loi et al. [21] by a 5-point Likert scale ( $1=$ strongly disagree; $5=$ strongly agree). For the last section of the survey, we applied share intention indicators from Babin et al. [28] by also using a 5-points Likert scale ( $1=$ strongly disagree; $5=$ strongly agree). Before we share the survey with our potential respondents, we conduct a wording test on five people with a different background. Every input from each people will be assessed and changing the content of indicators. Before we analyze with our main data, we conduct a pre-test for 30 respondents to measure whether our indicators are valid and reliable. The result of pre-testing in our 30 respondents is quite satisfying. All variables are considered as valid and reliable. There is no variable with KMO value below 0,5 and no variable has Cronbach's alpha below 0,7 .

The data analysis was conducted using Structural Equation Modeling-Partial Least Square (SEM-PLS). We use SPSS and SmartPLS version 3 to analyze our main data. At the beginning, we conduct pre-testing to 30 respondents and test the validity and reliability of our questionnaires. The validity and reliability of the variables and indicators used in this study are all valid and reliable. After that, we analyze our main data by calculating measurment model and structural model. In the measurement model, we want to see whether our indicators are fit enough to the model by calculating the validity and reliability. Then, we measured the structural model to see the correlation between latent variables in our model and to calculate the proposed hypotheses. 


\section{Results And Discussion}

\subsection{Measurement Model}

In measurement method analysis, we need to make sure that our model and data are valid and reliable. The initial step is calculating AVE value for each variable. AVE value for the cognitive image is 0.742 , which is exceed the critical number. From this analysis, we need to reduce three indicators from the first and second dimensions. We also reduce one indicator on each third and fourth dimension. After we reduce those indicators, we have good AVE values for each dimension on cognitive image. The same condition has also appeared in the unique image construct where we have three dimensions in this study. We only reduce one indicator from the "Appealing destination" dimension to meet the considerable AVE value for the unique image construct. It has an AVE value of 0.4968. For the affective image, overall image, satisfaction, share intention and revisit intention have AVE value of $0.688,1.000$, $0.690,0.787$, and 0.905 respectively. All variables meet the AVE critical value. For the reliability testing, we used composite reliability (CR) to make sure that all the variables we used are reliable. Based on Hair et al. [29], value above 0.6 can be acceptable for the research. All variables in this study are met the conditions since all have more than 0.7 . This is the reason why we still keep the AVE value of a unique image dimension even though it has a value below 0.50 .

\subsection{Structural Model}

The coefficient determinant (R2) of the endogenous variables are considered moderate. Overall image has $\mathrm{R} 2=0.540$, revisit intention has 0.418 , satisfaction has 0.443 , and share intention in 0.500. Based on Hair et al. [29], R2 value has been segmented into three parts; 0.25 considered has a weak prediction, 0.50 is moderate, and 0.75 is high prediction accuracy.

Table 2. Hypothesis Test Results.

\begin{tabular}{|c|c|c|c|c|c|c|}
\hline Relationship & Std Beta & Std Error & t-value & Decision & $95 \%$ CI LL & $95 \%$ CI UL \\
\hline $\begin{array}{c}\text { Cognitive Image -> } \\
\text { Overall Image }\end{array}$ & 0.22 & 0.07 & $3.23 * *$ & Supported & 0.10 & 0.32 \\
\hline $\begin{array}{l}\text { Affective Image -> } \\
\text { Overall Image }\end{array}$ & 0.46 & 0.06 & $7.69 * *$ & Supported & 0.36 & 0.56 \\
\hline $\begin{array}{l}\text { Unique Image -> } \\
\text { Overall Image }\end{array}$ & 0.18 & 0.05 & $3.43 * *$ & Supported & 0.10 & 0.27 \\
\hline $\begin{array}{l}\text { Overall Image -> } \\
\text { Satisfaction }\end{array}$ & 0.67 & 0.04 & $\begin{array}{c}16.38^{*} \\
*\end{array}$ & Supported & 0.60 & 0.73 \\
\hline $\begin{array}{l}\text { Overall Image -> } \\
\text { Share Intention }\end{array}$ & 0.18 & 0.06 & $2.93 * *$ & Supported & 0.08 & 0.28 \\
\hline $\begin{array}{l}\text { Overall Image -> } \\
\text { Revisit Intention }\end{array}$ & 0.30 & 0.07 & $4.29 * *$ & Supported & 0.18 & 0.41 \\
\hline $\begin{array}{c}\text { Overall Image -> } \\
\text { Satisfaction -> Share } \\
\text { Intention }\end{array}$ & 0.38 & 0.04 & $9.75^{* *}$ & Supported & 0.32 & 0.45 \\
\hline $\begin{array}{c}\text { Overall Image -> } \\
\text { Satisfaction -> } \\
\text { Revisit Intention }\end{array}$ & 0.27 & 0.05 & $5.73 * *$ & Supported & 0.20 & 0.35 \\
\hline
\end{tabular}


From table 2, we can see that all hypotheses in the model are failed to be rejected. The result explains that affective image has the strongest impact on the overall image of Yogyakarta with a standardized coefficient of 0.46 and a t-value of 7.69. Then, the unique image comes at the second with a standardized coefficient of 0.18 and a t-value of 3.43 , and the cognitive image has the least impact on overall image Yogyakarta with a standardized coefficient of 0.22 and a t-value of 3.23. Then, the positive image of Yogyakarta itself will positively affect satisfaction higher than the tourist's behaviors. Hypothesis 4 has a standardized coefficient of 0.67 and a t-value of 16.38, while the overall image to share intention has a standardized coefficient of 0.18 and a t-value of 2.93. The overall image has also positively affected the intention to revisit Yogyakarta with a standardized coefficient of 0.30 and a t-value of 4.29 . Hypotheses 7 and 8 tested the mediating role of satisfaction on the relationship between the overall image and tourist's future behaviors. The test concludes that both hypotheses are also failed to be rejected. We used VAF (Variance Accounted For) analysis to determine the mediation type [29]. VAF of satisfaction in the relationship of overall image and share intention is 0.68 , while VAF of satisfaction in the relationship of overall image and revisit intention is 0.48 . Both values are indicating that satisfaction has a partial mediation effect in this model.

All dimensions of destination image in this study; cognitive image, affective image, and unique image have a significant result on the forming of a positive overall image of Yogyakarta. Echtner \& Ritchie and Beerli \& Martin [16],[3] say that the dimensions of the destination image that form the overall image consist of the cognitive value of one destination and affective emotions towards the destination visited. Other research also supports the theory that the destination image is broadly represented by a cognitive image and an affective image [6], [2], [27], [1]. The affective image has the biggest impact amongst the other dimensions, while the cognitive image has the least impact on the overall image. This result contradicts what Baloglu and McCleary [2] said that cognitive image value should have a greater impact on the overall image when the tourists have visited the destination. The result is also different from $\mathrm{Qu}$ et al. [7] where the cognitive image has the biggest impact on their study in Oklahoma, while the affective image has the least impact. However, this study has a similar result with the Jalilvand and Heidari [12] for Iran and the study of Santana and Gosling [11] for Ilheus city in Brazil. The difference could be affected by the time when we gather our data. $\mathrm{Qu}$ has conducted the data gathering on the gate of the arrival of Oklahoma City, while this study has been conducting through online questionnaire for the tourists who have traveled to Yogyakarta for the last one year. The result of this study has also confirmed the prior studies which stated destination image of a certain destination can positively impacting tourist's intention to share their experience and intention to revisit the place in the future. This results are similar with Loi et al. [21] who stated that destination image has a direct impact on revisit intention on the other day. This study also similar what Qu et al. and Prayag et al. [7][24] that are stated destination image has a direct impact on share intention via electronic word-ofmouth. Based on Wang et al. [30], destination image is one of antecedents of tourists loyalty. Tourist loyalty can be depicted by revisit and share intention via electronic word-of-mouth [31]. In Yogyakarta context, destination image also has a positive correlation with the level of satisfaction of the tourists. They will feel more satisfied when the overall image of Yogyakarta was perceived in a very positive value and vice versa. Yoon and Uysal [23] have stated that satisfaction can be so important for the tourism industry since can affect the destination choice and tourists loyalty such revisit and share the experience of the place. That is why the satisfaction of tourists in Yogyakarta can mediate the overall image of Yogyakarta and the tourist's future behaviors towards Yogyakarta tourism. 


\section{Conclusion}

The results of this study confirm the previous literature that destination image has a positive impact on tourist's intention to recommend and their intention to revisit the destination [7] for Yogyakarta. Cognitive image, affective image, and unique image have positive impact on the overall image of Yogyakarta in tourists ${ }^{6}$ mind. Satisfaction will be perceived positively when the tourists perception about Yogyakarta tourism is positive. The positive overall image of Yogyakarta also has an impact on tourists intention to revisit Yogyakarta or even to share a positive story to their relatives. This result implies that the stakeholders, especially the local government of Yogyakarta need to improve the cognitive and unique factors of the tourism industry in Yogyakarta such as creating a bilateral agreement with other countries to have a direct flight to Yogyakarta. So far, only Singapore and Malaysia have a direct flight to Yogyakarta. Then, creating unique welcoming centers in the middle of the city can improve the value of the industry that can ease tourists to find information about tourism in Yogyakarta. Last but not least, the data tells us that Yogyakarta cultural traditions value still lacks among tourist's perceptions. However, we can see a few cultural events held annually in Yogyakarta. The problem may lie in the awareness of some tourists about the events. So, the government should create massive advertising globally to create more awareness on international tourists about the cultural events in Yogyakarta. So far, what the Indonesia government did is more on posting Borobudur temple or Prambanan temple for global advertising. However, this study has some limitations that can be improved in future studies. The number of international tourists in this study still limited due to the Covid-19 pandemic. These international tourists in this study also heterogenous, so by concentrating the respondents to one continent only such Asia can create better managerial implications for the Yogyakarta tourism industry. Since the data collection method can influence the tourist's perception of the image of the destination, future research should collect the data directly on Yogyakarta while the tourists are having their experience in the city.

\section{References}

[1] Baloglu, S., \& McCleary, K. (1999). A model of destination image formation. Annals of Tourism Research, 26(4), 868-897.

[2] Byon, K. K., \& Zhang, J. J. (2010). Development of a scale measuring destination image. Marketing Intelligence \& Planning.

[3] Beerli, A., \& Martin, J. D. (2004). Factors influencing destination image. Annals of tourism research, 31(3), 657-681.

[4] Agapito, D., Oom do Valle, P., \& da Costa Mendes, J. (2013). The cognitive-affective-conative model of destination image: A confirmatory analysis. Journal of Travel \& Tourism Marketing, 30(5), 471-481.

[5] Gartner, W. C. (1994). Image formation process. Journal of travel \& tourism marketing, 2(2-3), 191-216.

[6] Hosany, S., Ekinci, Y., \& Uysal, M. (2006). Destination image and destination personality: An application of branding theories to tourism places. Journal of business research, 59(5), 638-642.

[7] Qu, H., Kim, L. H., \& Im. H. H. (2011). A Model of Destination Branding: Integrating the Concepts of The Branding and Destination Image. Tourism Management, 32(3), 465-476.

[8] Hanzaee, K. H., \& Saeedi, H. (2011). A model of destination branding for Isfahan city: Integrating the concepts of the branding and destination image. Interdisciplinary Journal of Research in Business, 1(4), 12-28. 
[9] Lin, C. H., \& Kuo, B. Z. L. (2018). The moderating effects of travel arrangement types on tourists' formation of Taiwan's unique image. Tourism Management, 66, 233-243.

[10] Llodrà-Riera, I., Martínez-Ruiz, M. P., Jiménez-Zarco, A. I., \& Izquierdo-Yusta, A. (2015). A multidimensional analysis of the information sources construct and its relevance for destination image formation. Tourism management, 48, 319-328.

[11] Santana, L. D., \& Sevilha Gosling, M. D. (2018). Dimensions of Image: A Model of Destination Image Formation. Tourism Analysis, 23(3), 303-322.

[12] Jalilvand, M. R., \& Heidari, A. (2017). Comparing face-to-face and electronic word-of-mouth in destination image formation. Information Technology \& People.

[13] Boulding, K. E. (1956). The image: Knowledge in life and society (Vol. 47). University of Michigan press.

[14] Crompton, J. L. (1979). Motivations for pleasure vacation. Annals of tourism research, 6(4), 408424.

[15] Lopes, S. D. F. (2011). Destination image: Origins, developments and implications. PASOS. Revista de Turismo y Patrimonio Cultural, 9(2), 305-315.

[16] Echtner, C. M., \& Ritchie, J. B. (1993). The measurement of destination image: An empirical assessment. Journal of travel research, 31(4), 3-13.

[17] Keller, K. L. (2008). Strategic brand management: Building, measuring, and managing brand equity (3rd ed.). New Jersey: Prentice Hall.

[18] Abubakar, B., \& Mavondo, F. (2014). Tourism destinations: Antecedents to customer satisfaction and positive word-of-mouth. Journal of Hospitality Marketing \& Management, 23(8), 833-864.

[19] Oliver, R. L. (1980). A cognitive model of the antecedents and consequences of satisfaction decisions. Journal of marketing research, 17(4), 460-469.

[20] Solomon, M. R., White, K., Dahl, D. W., Zaichkowsky, J. L., \& Polegato, R. (2017). Consumer behavior: Buying, having, and being. Boston, MA: Pearson.

[21] Loi, L. T. I., So, A. S. I., Lo, I. S., \& Fong, L. H. N. (2017). Does the quality of tourist shuttles influence revisit intention through destination image and satisfaction? The case of Macao. Journal of Hospitality and Tourism Management, 32, 115-123.

[22] Wang, C. Y., \& Hsu, M. K. (2010). The relationships of destination image, satisfaction, and behavioral intentions: An integrated model. Journal of Travel \& Tourism Marketing, 27(8), 829843.

[23] Yoon, Y., \& Uysal, M. (2005). An examination of the effects of motivation and satisfaction on destination loyalty: a structural model. Tourism management, 26(1), 45-56.

[24] Prayag, G., Hosany, S., Muskat, B., \& Del Chiappa, G. (2017). Understanding the relationships between tourists' emotional experiences, perceived overall image, satisfaction, and intention to recommend. Journal of Travel Research, 56(1), 41-54.

[25] Chi, C. G. Q., \& Qu, H. (2008). Examining the structural relationships of destination image, tourist satisfaction and destination loyalty: An integrated approach. Tourism management, 29(4), 624-636.

[26] Russel, J. A., Ward, L. M., \& Pratt, G. (1981). Affective quality attributed to environments: a factor analytic study. Environment and Behavior, 13(3), 259e288.

[27] Stern, E., \& Krakover, S. (1993). The formation of composite urban image. Geographical Analysis, 25(2), 130e146.

[28] Babin, B. J., Lee, Y. K., Kim, E. J., \& Griffin, M. (2005). Modeling consumer satisfaction and word-of-mouth: restaurant patronage in Korea. Journal of Services Marketing.

[29] Hair Jr, J. F., Hult, G. T. M., Ringle, C., \& Sarstedt, M. (2016). A primer on partial least squares structural equation modeling (PLS-SEM). Sage publications.

[30] Wang, B., Yang, Z., Han, F., \& Shi, H. (2017). Car tourism in Xinjiang: The mediation effect of perceived value and tourist satisfaction on the relationship between destination image and loyalty. Sustainability, 9(1), 22

[31] Zhang, H., Fu, X., Cai, L. A., \& Lu, L. (2014). Destination image and tourist loyalty: A metaanalysis. Tourism management, 40, 213-223. 